\title{
Effect of Detergent and Antibiotic Residuals on Proteolytic Activity of Plasmin on Beta Casein
}

\author{
Nahed Soliman and Eman El Dakhakhny 1
}

\begin{abstract}
Plasmin plays a significant role in cheese ripening and characteristics of dairy products. The antibiotic could be presented in milk as residuals from animal treated by antibiotic, while presence of detergent could be as residuals from cleaning of milking machines, tanks during transpirations, storage tanks and pasteurization equipments etc. The effect of detergents and antibiotic residuals on proteolytic action of plasmin on $\beta$-casein in model solution was determined by Urea-polyacrylamide gel electrophoresis. The results suggested that plasmin followed the proteolytic pathway on cow $\beta$-casein to produce $\gamma_{1}, \gamma_{2}$ and $\gamma_{3}$ as the degradation fragments. The proteolytic pathway has been affected by presence of sodium hydroxide and nitric acid, while was not affected by presence of antibiotic. The results also indicated that the presence of sodium hydrioxid increased the plasmin activity, while plasmin hydrolysate of B-casein slightly inhibited by nitric acid. The proteolytic activity of plasmin on $\beta$-casein was broader and higher at the end of incubation period, to yield low-sized fragments as evidenced with polyacrylamide gel electrophoresis. Increased plasmin activity by sodium hydroxide residual could affect cheese making characteristics such as the rennet coagulation time, curd strength, and curd syneresis, produce off-flavor and bitterness in cheese. Since the plasmin is heat stable enzyme, increasing its activity in UHT milk could case gelatoin and produce off-flavor and bitterness.
\end{abstract}

Key Words: plasmin, $\beta$-casein, detergent and antibiotic residuals.

\section{INTRODUCTION}

Plasmin (fibrinolysin E.C.3.4.21.7), the principle indigenous proteinase in milk, is a serine proteinase with trypsin- like activity with $\mathrm{pH}$ optimum of $\sim 7.5$, it cleaves bonds of the type Lys $-\mathrm{X}$ and to a lesser extent, Arg- X. The properties and significance of plasmin have been extensively reviewed (Bastian and Brown, 1996). In milk, $\alpha_{\mathrm{s} 1}$ and $\beta$ - casein are hydrolysed rapidly by plasmin (Andrews and Alichanidis, 1983). $\alpha_{\mathrm{s} 1}-$ casein is degraded more slowly, while $\kappa$-casein is very resistant (Eigel, 1977). Plasmin activity results in the formation of $\gamma$-casein, $\lambda$-casein and proteose peptone. $\gamma$-casein results from the hydrolysis of $\beta$-casein by plasmin (Swaisgood, 1982), while $\lambda$-casein fraction consists of peptides produced from $\alpha_{\mathrm{s} 1}-$ casein (Aimutis and Eigel, 1982). The proteose peptone fraction consists mainly of peptides produced from casein by the action of plasmin
(Andrews and Alichanidis, 1983). The specificity of plasmin on $\beta$-casein is well documented (Eigel, 1977 and 1981). As well as producing $\gamma_{1}-(\mathrm{B}-\mathrm{CNF} 29-209)$, $\gamma_{2}-(\mathrm{B}-\mathrm{CNF}-106-209), \gamma_{3}-(\mathrm{B}-\mathrm{CNF}-108-209)$ casein and their complementary $\mathrm{N}$ - terminal peptides, plasmin can also cleave bonds $\mathrm{Lys}_{113}-\mathrm{Lys}_{114}$ and $\mathrm{Arg}_{183}-\mathrm{Asp}_{184}$ in $\beta$ - casein fairly rapidly (Le Bars and Gripon, 1993). Enzyme activity increased in milk with stage of lactation, severity of mastitis infection and lactation number (Eric and Rodney, 1995). Since plasmin is strongly associated with the casein micelles in milk, it is incorporated into the curd during cheese - making and is active in cheese during ripening. The level of plasmin activity depends on the cheese variety (Cait and Patrick, 1999). In ripened cheese, such as cheddar, plasmin activity is evident by the limited hydrolysis of $\beta$-casein with a concomitant increase in the $\gamma$-casein. The extent to which plasmin contributes to proteolysis during ripening is well defined and it was thought for a long time to be limited to the slow hydrolysis of $\beta$-casein. However, Farkye and Fox (1991 and 1992) found that plasmin contributes to both the level and type of water soluble peptides formed from casein during cheddar cheese ripening. The enzyme is heat resistant and survives many UHT treatments, but its role in the gelation of UHT - treated milk is not fully understood (Eric and Rodney, 1995).

Proteolysis of proteins is the major activity attributed to plasmin in the milk. Casein is most susceptible to breakdown by this enzyme. Among the various classes of casein, $\beta$-casein is more susceptible than $\alpha$ s-casein, and $\mathrm{k}$-casein is somewhat resistant to breakdown by the plasmin. Breakdown fragments of casein can produce off-flavor and bitterness in milk. In contrast, milk whey proteins such as $\alpha$-lactalbumin and $\beta$-lactoglobulin are fairly resistant to the action of plasmin (Bastian and Brown 1996).

Increase plasmin activity decreases the viscosity of a caseinate solution. This is especially noticed in milk from older cows which has higher plasmin activity. Plasmin affects cheese making characteristics of milk such as the rennet coagulation time, curd strength, and curd syneresis (Sousa et al., 2001). Mozzarella cheese made from late lactation milk, which contains higher amounts of plasmin, has inferior stretchability and melting ability. Proteolysis of casein by plasmin also

${ }^{1}$ Dairy Science and Technology Department, Faculty of Agriculture, Alexandria University.

Received May25, 2010, Accepted June 12, 2010 
increases the moisture content in cheddar cheese. Swiss cheese contains higher plasmin activity than cheddar cheese because the higher cooking temperature required for Swiss cheese destroys the inhibitors of plasmin and plasminogen activators. As a result, more breakdown of casein occurs during ripening of Swiss cheese as compared to cheddar cheese (Bastian and Brown 1996).

The dirt on tanks, pipes, cheese vats and other surfaces is normally clean with alkaline and acid detergents. The milk may contain residues of antibiotics emanating from treatment of cows suffering from mastitis; the most commonly occurring one is penicillin.

No data are available from studing the effecting of detergents and antibiotic residuals on proteolytic activity of plasmin in milk and cheese. The objective of the present work was to determine the effect of detergents and antibiotic residuals on proteolytic action of plasmin on $\beta$-casein in model solution by analysing the degradation products using urea-polyacrylamide gel electrophoresis.

\section{MATERIALS AND METHODS}

\section{Materials}

Bovine plasmin (fibrinolysin, E.C.3.4.21.7, from bovine plasma) was obtained from Sigma chemicals. It was dissolved in distilled water $(34.46 \mathrm{mg} / \mathrm{L})$; this solution had 1.3 units of plasmin activity, where 1 unit is the amount of enzyme that will produce a $\Delta \mathrm{A}_{275}$ of 10 from $\alpha_{\mathrm{s} 1}-$ casein in $20 \mathrm{~min}$ at $\mathrm{pH} 7.5$ and $37^{\circ} \mathrm{C}$.

$\boldsymbol{\beta}$-casein was obtained from Sigma chemicals. It was assessed by urea- polyacrylamide gel electrophoresis (PAGE).

Detergents: Sodium hydroxide and Nitric acid were added individually at concentrations of 20 and $50 \mathrm{mg} / \mathrm{L}$, respectively.

Antibiotics: Draxin (antibiotic1) and Marbocyl( antibiotic2) were added individually at concentrations of 50 and $100 \mathrm{mg} / \mathrm{L}$, respectively.

\section{Preparation of $\boldsymbol{\beta}$-casein solution}

$\beta$-casein $(5 \mathrm{mg} / \mathrm{L})$ was dissolved in $0.1 \mathrm{M}$ sodium citrate buffer at $\mathrm{pH}$ 8. Sodium azide $\left(\mathrm{NaN}_{3} ; 0.02 \%\right.$, $\mathrm{w} / \mathrm{v}$ ) was added to the solution (and all other solutions) to inhibit bacterial growth. The solution was stirred for 1 $\mathrm{h}(\mathrm{pH}$ 7.6) followed by the addition of $4-5$ drops of 0.1 or $1 \mathrm{~N} \mathrm{HCl}$ to adjust the $\mathrm{pH}$ at 7.0 by stirring for $15 \mathrm{~min}$. Such solution was transferred into the refrigerator and incubated overnight. After that, it was heated at $78{ }^{\circ} \mathrm{C}$ for $15 \mathrm{~min}$ followed by cooling at room temperature.

Hydrolysis conditions

1- Effect of antibiotics on the proteolysis of $\beta$-casein by bovine plasmin:
Solution of $\beta$-casein $(5 \mathrm{mg} / \mathrm{L})$ containing 0,50 or $100 \mathrm{mg} / \mathrm{L}$ of Draxin and Marbocyl individually prepared. Bovine plasmin $(0.25 \mathrm{U} / \mathrm{L})$ was added at $37^{\circ} \mathrm{C}$. Samples were taken after 0, 6, 12 and $24 \mathrm{~h}$ and heated at $100{ }^{\circ} \mathrm{C}$ for $15 \mathrm{~min}$ to inactivate plasmin.

2- Effect of detergent on the proteolysis of $\beta$-casein by bovine plasmin:

Solution of $\beta$-casein $(5 \mathrm{mg} / \mathrm{L})$ containing 0,20 or $50 \mathrm{mg} / \mathrm{L}$ Sodium hydroxide and Nitric acid were individually. Bovine plasmin $(0.25 \mathrm{U} / \mathrm{L})$ was added and the solution was incubated at $37{ }^{\circ} \mathrm{C}$. Samples were taken after $0,6,12$, and $24 \mathrm{~h}$ and heated at 100 ${ }^{\circ} \mathrm{C}$ for 15 min to inactivate plasmin.

\section{Urea - polyacrylamide gel electrophoresis (Urea - PAGE)}

Gel electrophoresis was performed according to the method of Andrews (1983) with separation gels of $\mathrm{T}=$ $12.5 \%, \mathrm{C}=4 \%$ and $4.5 \mathrm{M}$ Urea (separation gels buffer was composed of $4.6 \%$ Tris and its $\mathrm{pH}$ was adjusted to 8.9 by the addition of $\mathrm{HCl}$ ). The running buffer was composed of $15 \mathrm{~g}$ Tris and $73 \mathrm{~g}$ Glycine and was dissolved in $5 \mathrm{~L}$ of distilled water and gels were run at approximately $25 \mathrm{~V} / \mathrm{cm}$ for about $75-90 \mathrm{~min}$ until Bromophenol blue tracking dye was close to the bottom of the slab. Staining was carried out for $1 \mathrm{~h}$ in $0.25 \%$ (w/v) Coomassie brilliant blue G-250 dissolved in $50 \%$ methanol and $12.5 \%$ TCA, while destaining was carried out in a solution of $7 \%$ acetic acid. Sample buffer was $10 \%$ stacking gel buffer containing $8 \mathrm{M}$ Urea and $2 \% 2$ - mercaptoethanol, and $0.01 \%$ Bromophenol. $200 \mu 1$ of sample was dissolved in $1 \mathrm{ml}$ sample buffer and centrifuged at $5000 \mathrm{xg}$ for $30 \mathrm{~min}$ at $4{ }^{\circ} \mathrm{C}$. $5 \mu \mathrm{l}$ of each sample was applied to the gel.

\section{Gel scanning}

Band scanning was carried out by Toshiba Scanner. Quantitative determination of the fragments was made by Molecular Dynamic Image Quant v 5 software.

\section{RESULTS AND DISCUSSION}

The hydrolysis of $\beta$-casein by the plasmin during incubation time up to $24 \mathrm{~h}$ is shown in Figures 1, 2,3 and 4. Electrophoretic chromatogram shows that the action of plasmin on $\beta$-caseins released small molecular weight three peptides as evidenced by the relative electrophoretic mobility, since the most sensitive peptide bonds to plasmin are Lys $28^{-\mathrm{Lys}} 29$, Lys $105^{-}$ His 106 , and Lys $107-$ Glu$_{108}$ in cow $\beta$-Casein (Andrews, 1978 a,b).

The results showed that B-casein was degraded more rapidly by plasmin and high mobility peptides (peptide1, peptid 2 and peptid3) were produced after $1 \mathrm{hr}$. 


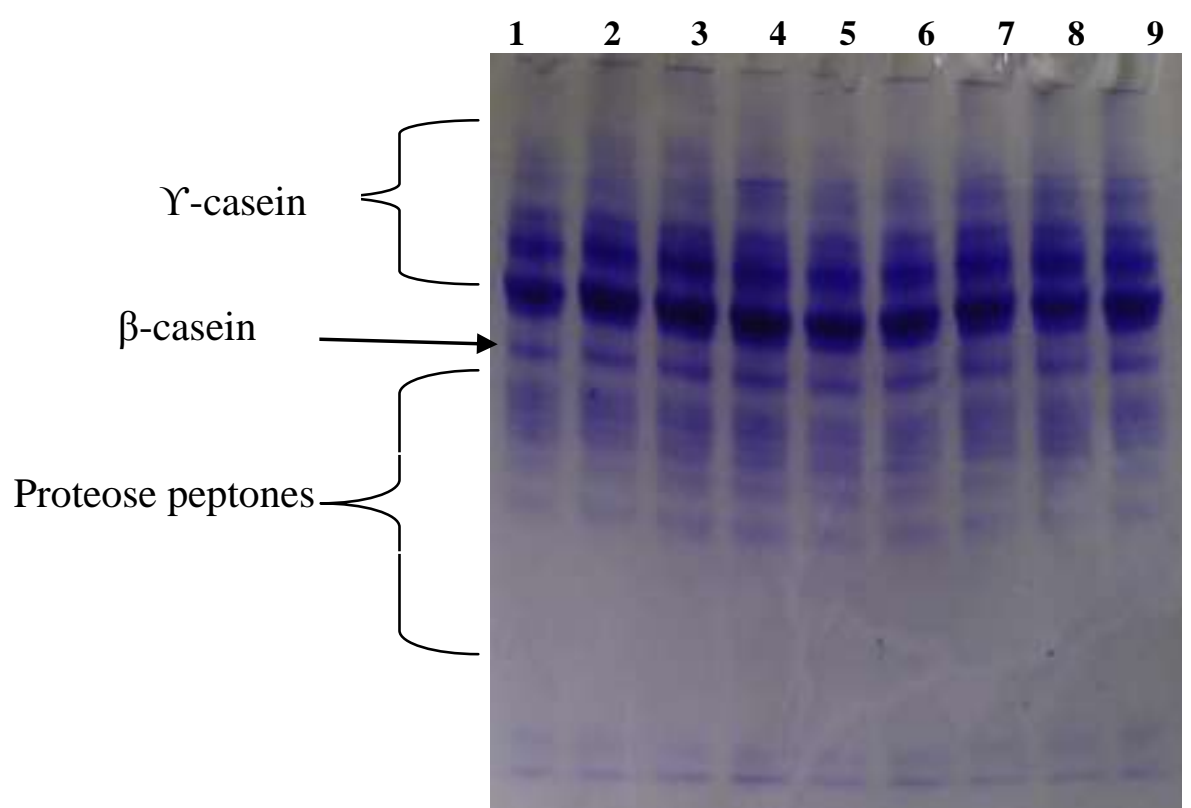

Figure 1. Urea-polyacrylamide gel electrophoresis of $\beta$-casein hydrolysed by plasmin at $\mathbf{1 h}$ in the presence of detergentand antibiotic residuals

Lane 1: control; lanes 2-3: antibiotic 1 at 100 and $50 \mathrm{mg} / \mathrm{lrespectively}$

Lanes 4- 5: antibiotic 2 at 100 and $50 \mathrm{mg} / \mathrm{l}$ respectively

Lanes 6-7: $\mathrm{NaOH}$ at 50 and $20 \mathrm{mg} / \mathrm{l}$ respectively

Lanes 8-9: $\mathrm{HNo}_{3}$ at 50 and $20 \mathrm{mg} / \mathrm{l}$ respectively



Figure 2. Urea-polyacrylamide gel electrophoresis of $\beta$-casein hydrolysed by plasmin at $6 \mathrm{~h}$ in the presence of detergent and antibiotic residuals Lane 1: control; lanes 2-3: antibiotic 1 at 100 and $50 \mathrm{mg} / \mathrm{l}$ respectively Lanes 4- 5: antibiotic 2 at 100 and $50 \mathrm{mg} / \mathrm{l}$ respectively Lanes 6-7: $\mathrm{NaOH}$ at 50 and $20 \mathrm{mg} / \mathrm{l}$ respectively Lanes 8-9: $\mathrm{HNo}_{3}$ at 50 and $20 \mathrm{mg} / \mathrm{l}$ respectively 


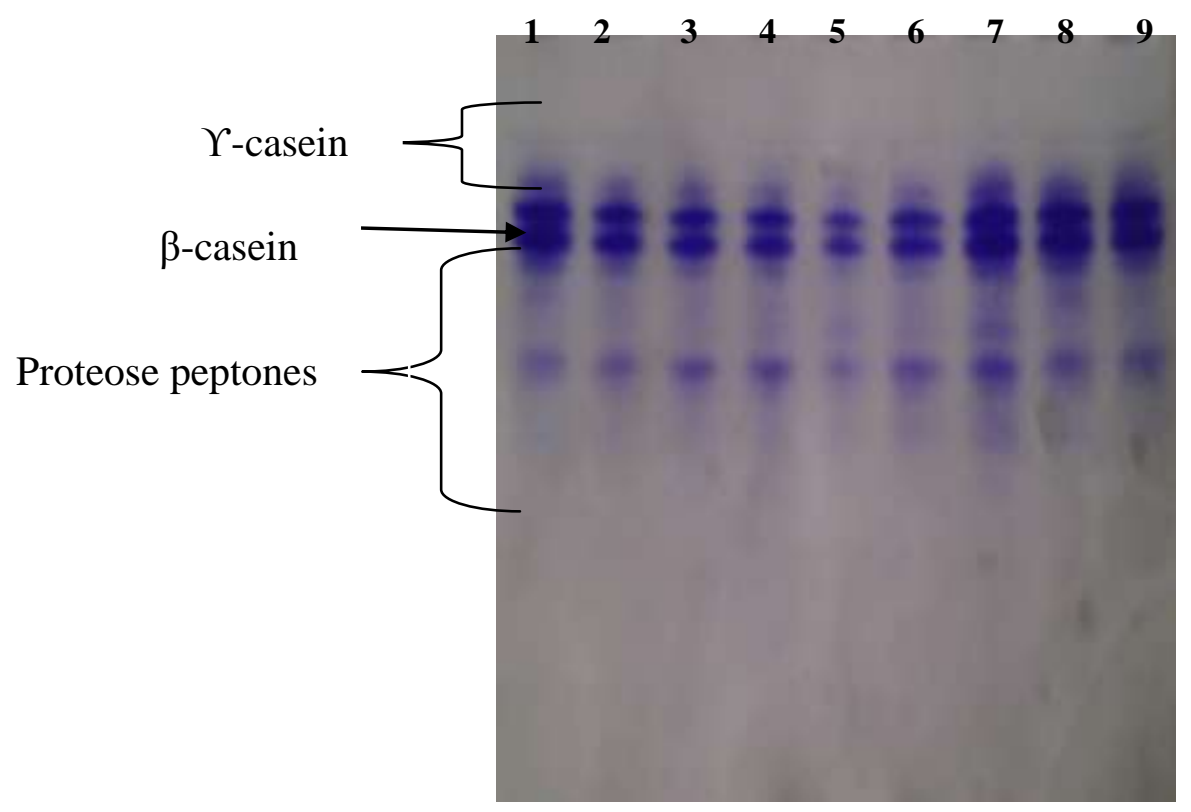

Figure 3. Urea-polyacrylamide gel electrophoresis of $\beta$-casein hydrolysed by plasmin at $12 \mathrm{~h}$ in the presence of detergent and antibiotic residuals

Lane 1: control; lanes 2-3: antibiotic 1 at 100 and $50 \mathrm{mg} / \mathrm{l}$ respectively

Lanes 4- 5: antibiotic 2 at 100 and $50 \mathrm{mg} / \mathrm{l}$ respectively

Lanes 6-7: $\mathrm{NaOH}$ at 50 and $20 \mathrm{mg} / \mathrm{l}$ respectively

Lanes 8-9: $\mathrm{HNo}_{3}$ at 50 and $20 \mathrm{mg} / \mathrm{l}$ respectively

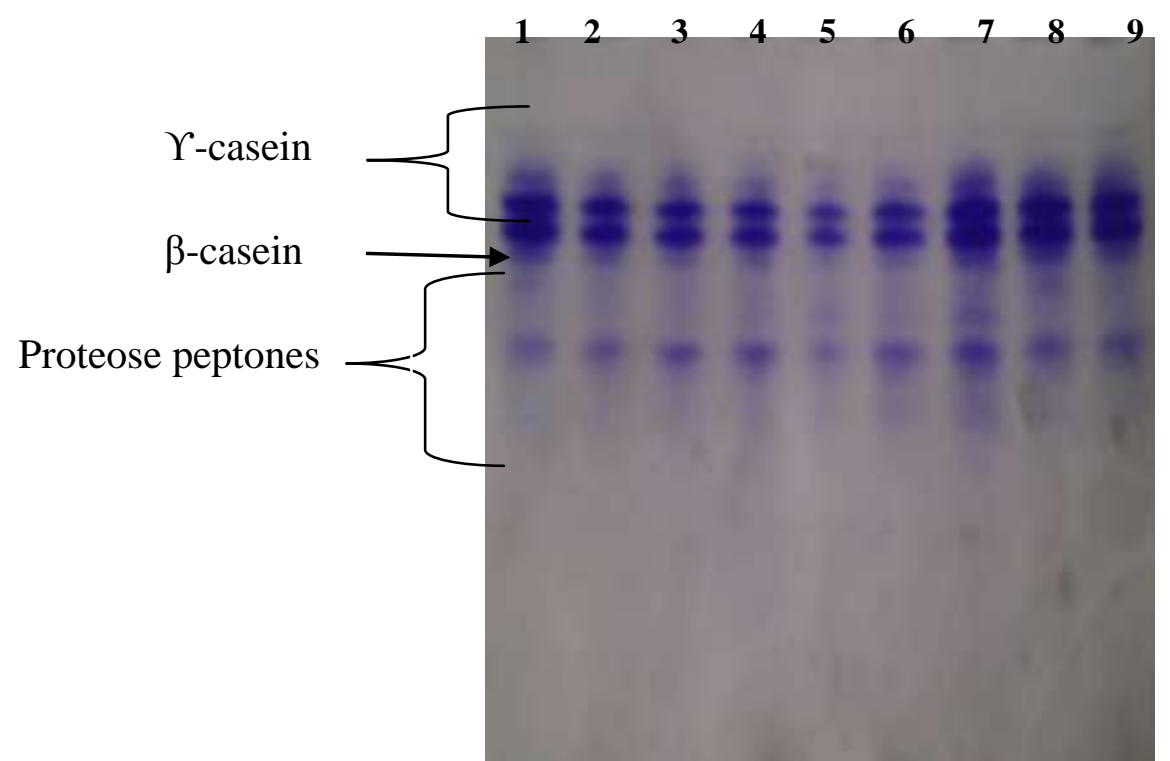

Figure 4. Urea-polyacrylamide gel electrophoresis of $\beta$-casein hydrolysed by plasmin at $24 \mathrm{~h}$ in the presence of detergent and antibiotic residuals

Lane 1: control; lanes 2-3: antibiotic 1 at 100 and $50 \mathrm{mg} / \mathrm{l}$ respectively

Lanes 4- 5: antibiotic 2 at 100 and $50 \mathrm{mg} / \mathrm{l}$ respectively

Lanes 6-7: $\mathrm{NaOH}$ at 50 and $20 \mathrm{mg} / \mathrm{l}$ respectively

Lanes 8-9: $\mathrm{HNo}_{3}$ at 50 and $20 \mathrm{mg} / \mathrm{l}$ respectively 
of incubation and their corresponding proteose pepton. Peptide1 was further hydrolysate and disappeared at the end of incubation time, but peptide 2 was gradually increased and not degraded during incubation period. This peptide is seen in all electrophoretic profile of all treatment. While peptide 3 was not clear during $24 \mathrm{hr}$. of incubation (figure 5 ). Low migration peptide which are known $\gamma$-casein on urea-PAEE (Awad 2002) were produced from B-casein after $1 \mathrm{hr}$. up to $6 \mathrm{hr}$. of incubation and degraded thereafter (Figures 1 and 5).The hydrolysate products of B-casein were previously isolated and identified by cait et al (1999).It should be noted that some of the small peptides produced by action of plasmin on B-casein or sodium caseimate.

The hydrolysis of B-casein by plasmin in presence antibiotics during $24 \mathrm{hr}$. incubation shown in (figures 1 ,
2, 3 and 4) There was no different between control and treatment of antibiotics (Draxin and Marbocyl) at both concentration used in this study (50 and $100 \mathrm{ml} / \mathrm{l})$ during $6 \mathrm{hr}$. of incubation. The hydrolysis of B-casein by plasmin was slightly increased during $12 \mathrm{hr}$. of incubation up to the end of incubation period specially in presence Marbocyl ( antibiotic2) (figure 6 and 7 ). Seaman et al (1988), measured somatic cell count, total proteolytic activity and plasmin activity in cow milk during pre-infection, infection and post infection by mastitis. All parameters increased significantly during infection, they concluded that even after curing mastitis, plasmin activity does not return to its pre-level

The electrophoretogram of plasmin hydrolysat of Bcasein shows that there was a high molecular weight of band corresponding to $\gamma$-casein was seen during $1 \mathrm{hr}$.

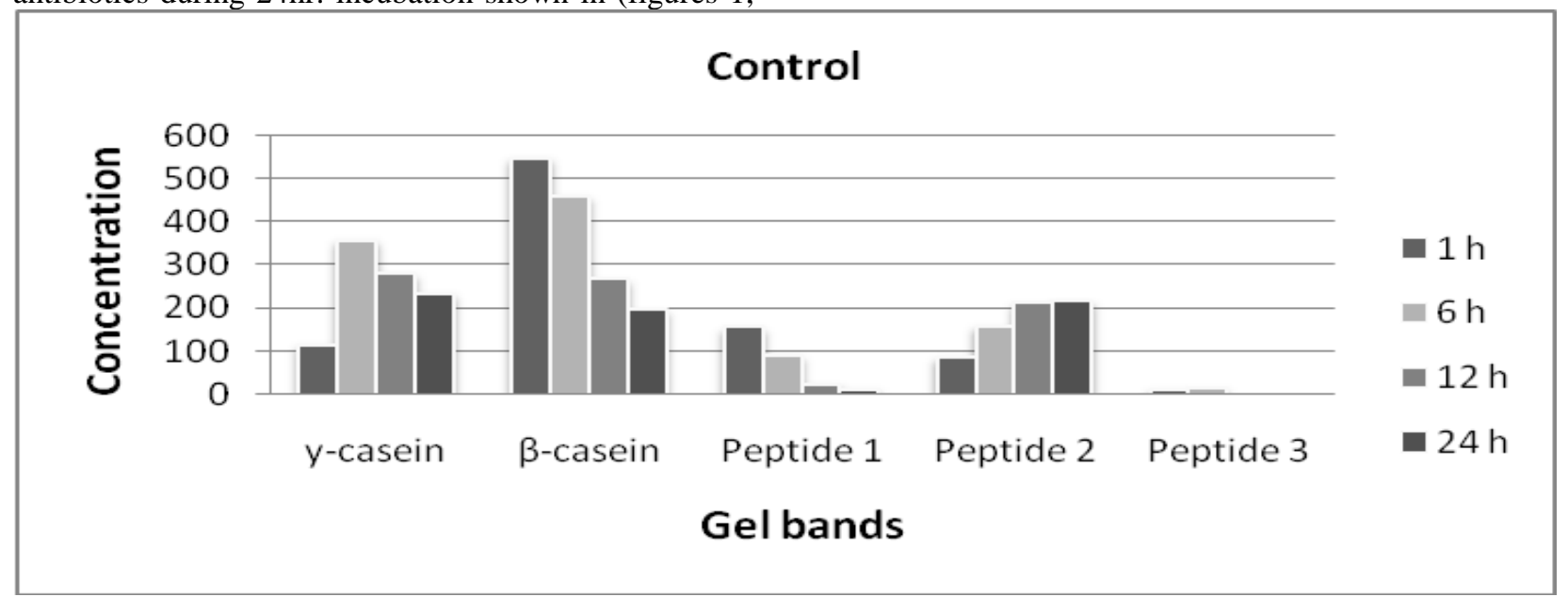

Figure 5. Scanning of Urea-polyacrylamide gel electrophoresis of $\beta$-casein hydrolysed by plasmin at 1, 6, 12 and $24 \mathrm{~h}$

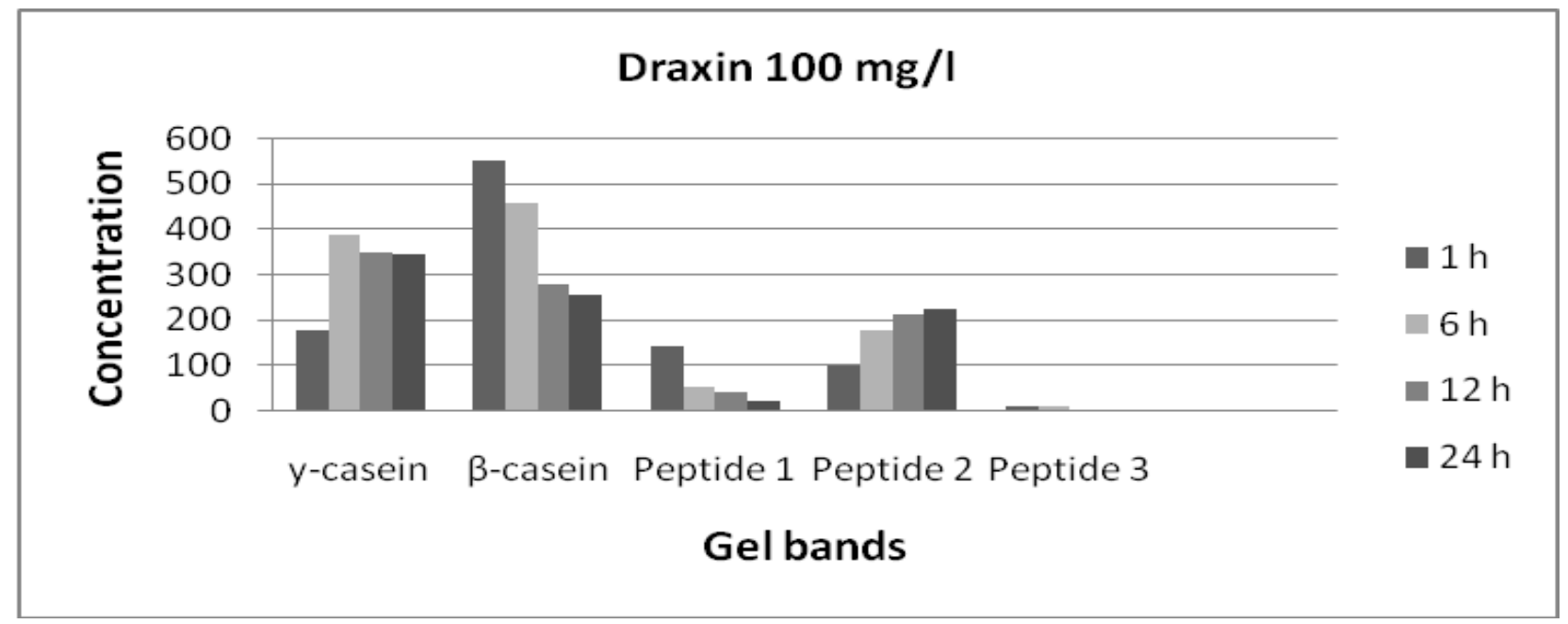

Figure 6. Scanning of Urea-polyacrylamide gel electrophoresis of $\beta$-casein hydrolysed by plasmin in the presence of Draxin antibiotic $(100 \mathrm{mg} / \mathrm{l})$ at $1,6,12$ and $24 \mathrm{~h}$ 


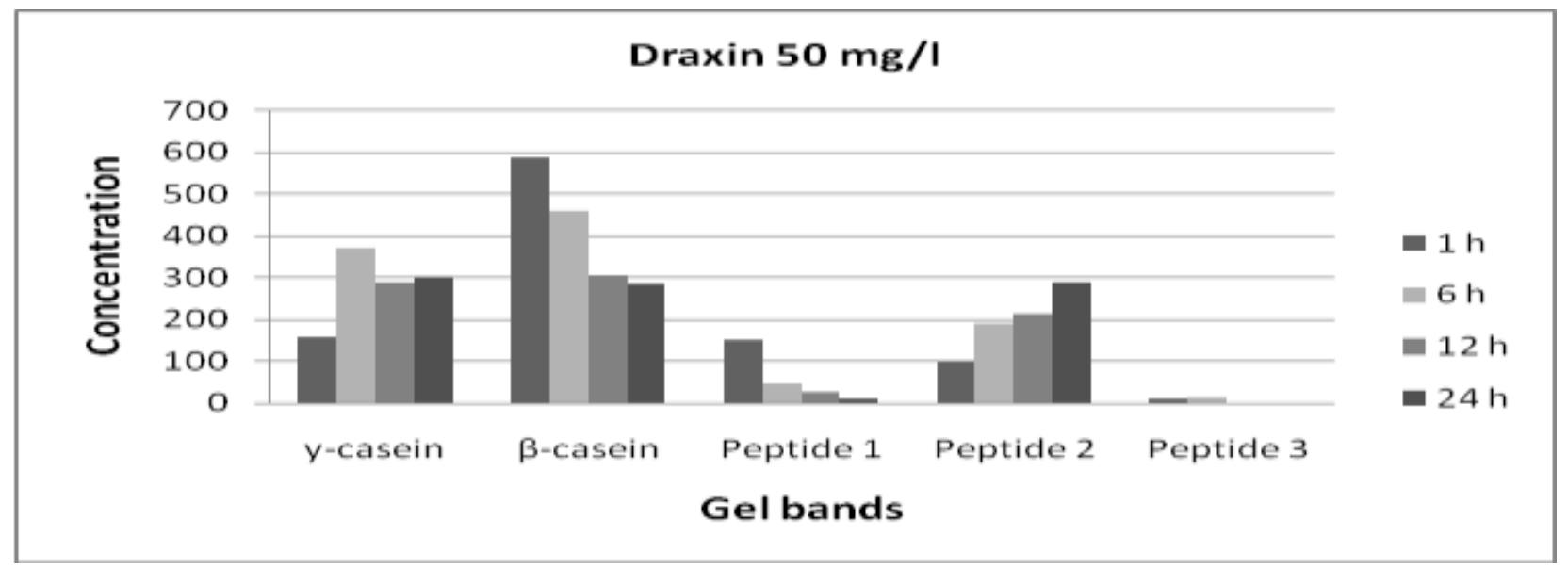

Figure7. Scanning of Urea-polyacrylamide gel electrophoresis of $\beta$-casein hydrolysed by plasmin in the presence of Draxin antibiotic $(50 \mathrm{mg} / \mathrm{l})$ at $1,6,12$ and $24 \mathrm{~h}$

The electrophoretogram of plasmin hydrolysat of Bcasein shows that there was a high molecular weight of band corresponding to $\gamma$ - casein was seen during $1 \mathrm{hr}$.up to $6 \mathrm{hr}$. of incubation and not degraded thereafter, while peptide 1 and peptide 2 were similar with control at all stage of incubation in both two antibiotics (fig 5,6,7,8 and 9) indicating that the specificity of plasmin was not influenced by antibiotics.

The rate of B-casein degradation by plasmin with added sodium hydroxide $(\mathrm{NaOH})$ at 20 and $50 \mathrm{mg} / \mathrm{l}$ during 24hr.of incubation shown in (figures 10 and 11) .Results indicated that the plasmin activity was increased by added $\mathrm{NaOH}$. B-casein was degraded by plasmin in presence of $\mathrm{NaOH}$ to high molecular weight peptides $(\gamma-$ casein, peptide 1,peptide 2) with electrophoretic mobilities faster than B- casein specially at $50 \mathrm{mg} / \mathrm{l}$ con.(figure10) and further more hydrolysed with increasing incubation time .All B-casein peptides were hydrolysed at faster rate than control and more degraded after $6 \mathrm{hr}$. of incubation and disappeared at the end of incubation, indicating that B-casein and its peptides were more susceptible to the enzyme at high $\mathrm{pH}$ values (Fox and stepaniak, 1993) suggested that $\beta$-casein is hydrolysed more quickly at high $\mathrm{pH}$ by indigenous or added plasmin. It is hydrolysed to $\gamma$-caseins and certain proteose peptones (PP). The $\gamma 1, \gamma 2$ and $\gamma 3$-caseins correspond to residues 29-209, 106-209 and 108-209 of $\beta$-casein, respectively. PP5 consists of two peptides corresponding to $\beta$-casein (f1-105) and (f1-107), PP8fast is $\beta$-casein (f1-28) and PP8-slow may be $\beta$-casein (f29-105/107).

Also results are shown some of high mobility peptide (peptide 3) that was detected at $1 \mathrm{hr}$. of incubation, then further hydrolysed and disappeared at the end of incubation in control while this peptide was not detected in presence of sodium hydroxide. Peptide2 was decreased with increasing the incubation time to reversely trend the control.

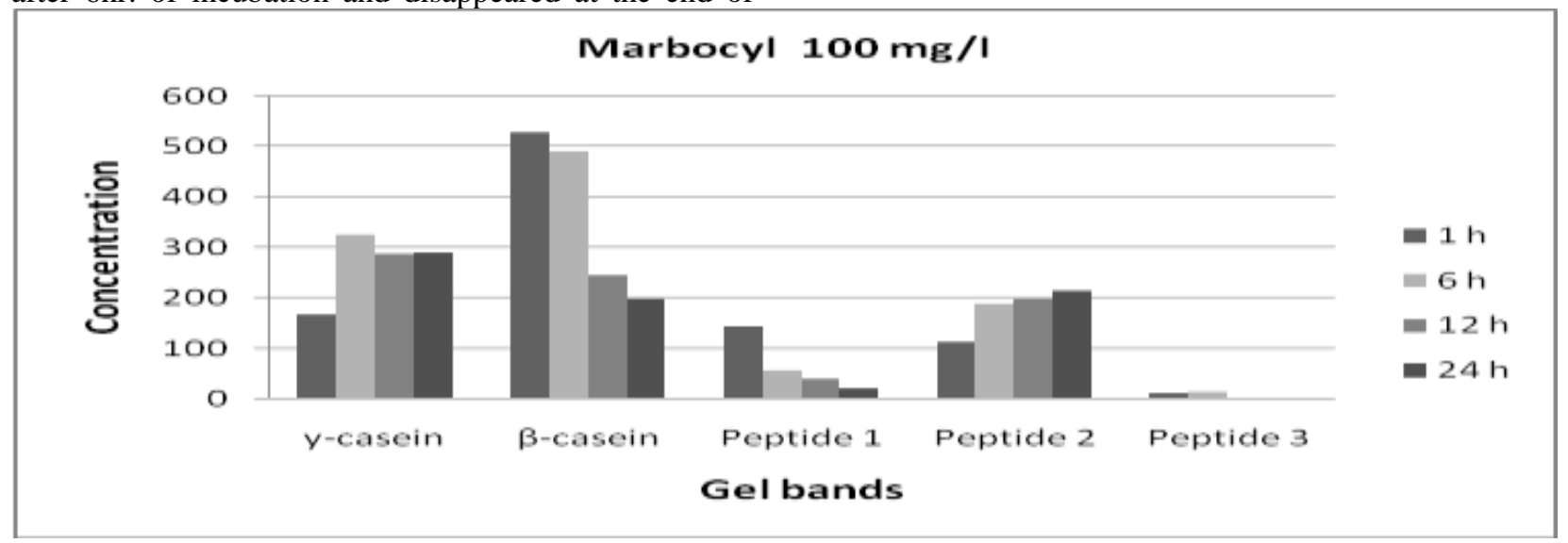

Figure 8. Scanning of Urea-polyacrylamide gel electrophoresis of $\beta$-casein hydrolysed by plasmin in the presence of Marbocyl antibiotic $(100 \mathrm{mg} / \mathrm{l})$ at 1, 6,12 and $24 \mathrm{~h}$ 


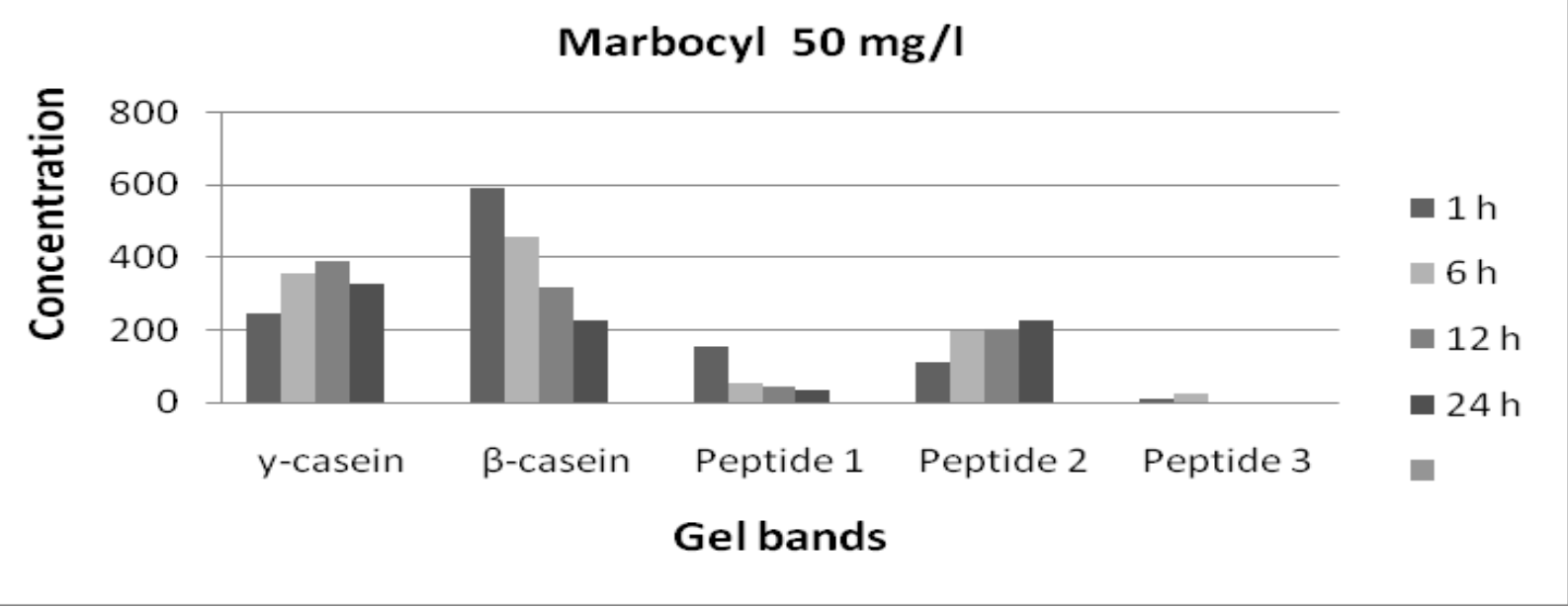

Figure 9. Scanning of Urea-polyacrylamide gel electrophoresis of $\beta$-casein hydrolysed by plasmin in the presence of Marbocyl antibiotic (50 mg/l) at 1, 6, 12 and $24 \mathrm{~h}$

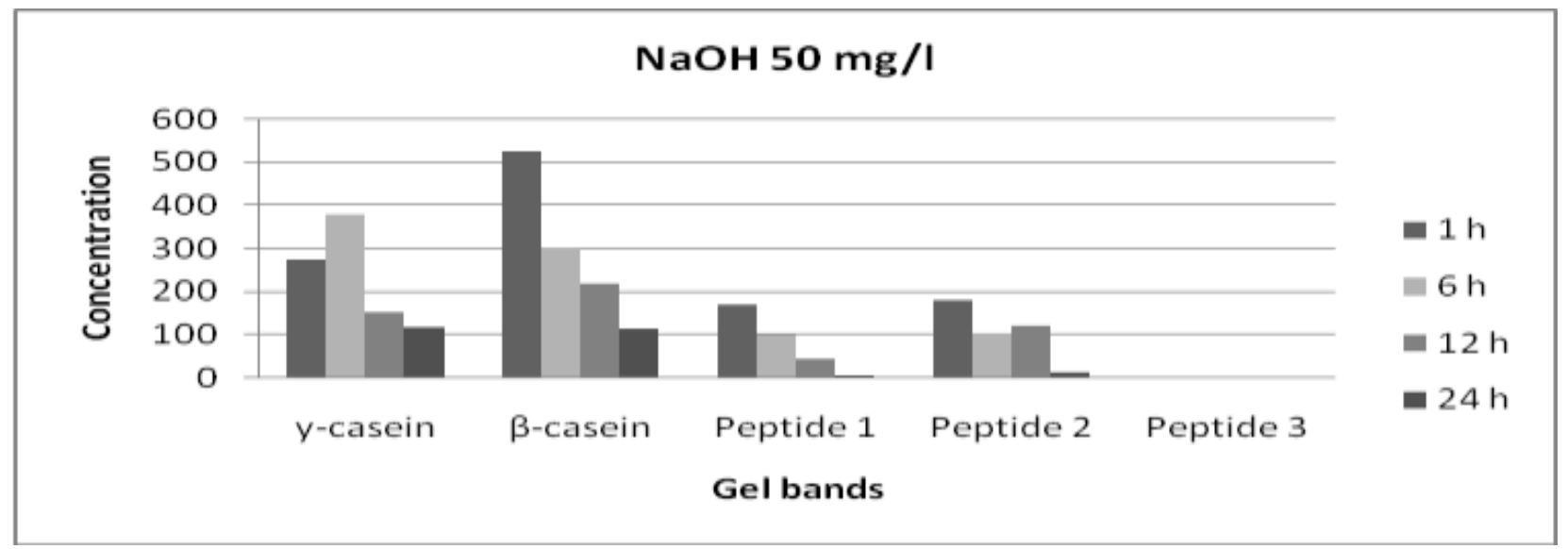

Figure 10. Scanning of Urea-polyacrylamide gel electrophoresis of $\beta$-casein hydrolysed by plasmin in the presence of $\mathrm{NaOH}(50 \mathrm{mg} / \mathrm{l})$ at $1,6,12$ and $24 \mathrm{~h}$

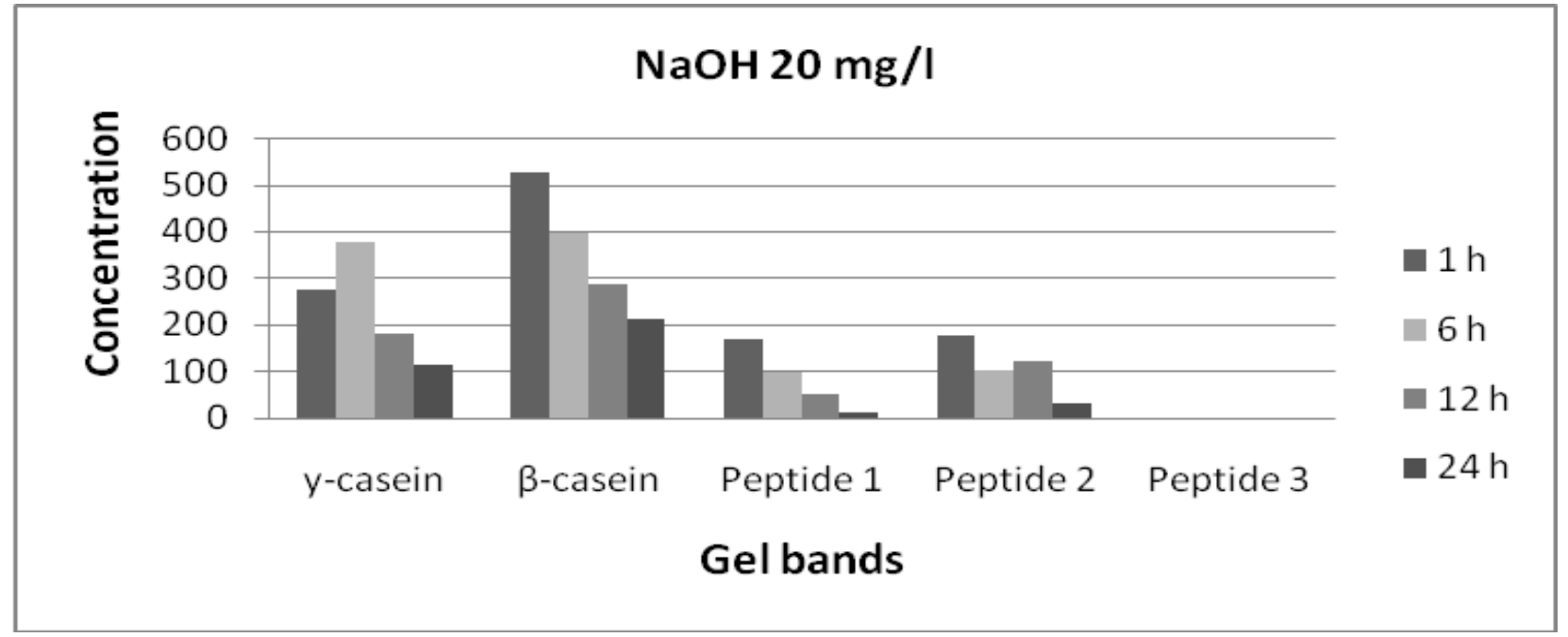

Figure11. Scanning of Urea-polyacrylamide gel electrophoresis of $\beta$-casein hydrolysed by plasmin in the presence of $\mathrm{NaOH}(20 \mathrm{mg} / \mathrm{l})$ at $1,6,12$ and $24 \mathrm{~h}$ 
The effect of Nitric acid on the hydrolysis of Bcasein by plasmin illustrated in (figure 12 and 13). The electrophoretograme of plasmin hydrolysat of B-casein was inhibited slightly by Nitric acid and more affected at high concentration $(5 \mathrm{o} \mathrm{mgl} / \mathrm{L})$. The bands of electrophorelogram corresponding to $\gamma$-casein, peptide 1 and peptide 2 were seen at low concentration in Bcasein hydrolysate after $6 \mathrm{hr}$. of incubation, these three bands migrated faster than B-casein could be seen after $1 \mathrm{hr}$. of incubation in control (figure 5). The $\gamma$-casein and proteose peptone( peptide 1 and peptide 2) in the electrophoretic profile of hydrolysate after $6 \mathrm{hr}$. incubation was not hydrolysate during $24 \mathrm{hr}$.of incubation (figure 4,12and 13).Lan and Fox (1999) showed that the activity of plasmin on B-casein was influenced by $\mathrm{pH}$, the rat of hydrolysis increased with increasing $\mathrm{pH}$ value from $\mathrm{pH} 6.5$ to 8.4.

\section{CONCLUSION}

Plasmin plays a significant role in cheese ripening and characteristics of dairy products. The antibiotic could be presented in milk as residuals from animal treated by antibiotic. While presence of detergent could be as residuals from cleaning of milking machines, tanks during transpirations, soil tanks, pasteurization equipments etc. Activity of plasmin is increased in present of small amounts of sodium hydroxide, this can increase degradation rate of casein and affect the processing of dairy products. Breakdown of milk proteins by proteases affects milk clotting, cheese ripening, and flavor and texture of dairy products. Breakdown fragments of casein by plasmin can produce off-flavor and bitterness in milk. Increased plasmin activity decreases the viscosity of a caseinate solution. Thickening, gelation, and coagulation of milk occurs during storage. This is also attributed to the proteolytic activity either from milk proteases such as plasmin or proteases of bacterial origin. Proteolytic activity caused by plasmin has a particular effect on the taste of milk (appearance of bitter peptides). Bitter peptides produced by the action of proteases influence the flavor of UHT milk, UHT cream, and cheese.

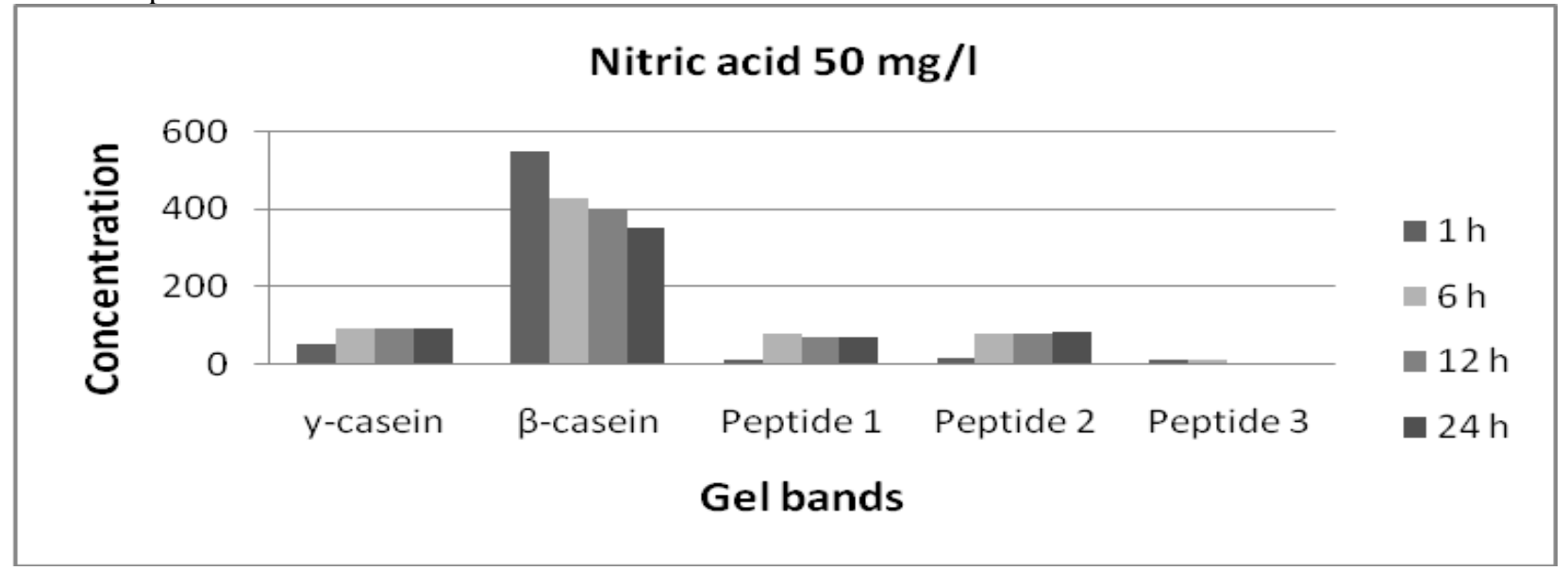

Figure 12. Scanning of Urea-polyacrylamide gel electrophoresis of $\beta$-casein hydrolysed by plasmin in the presence of $\mathrm{HNo}_{3}(50 \mathrm{mg} / \mathrm{l})$ at $1,6,12$ and $24 \mathrm{~h}$

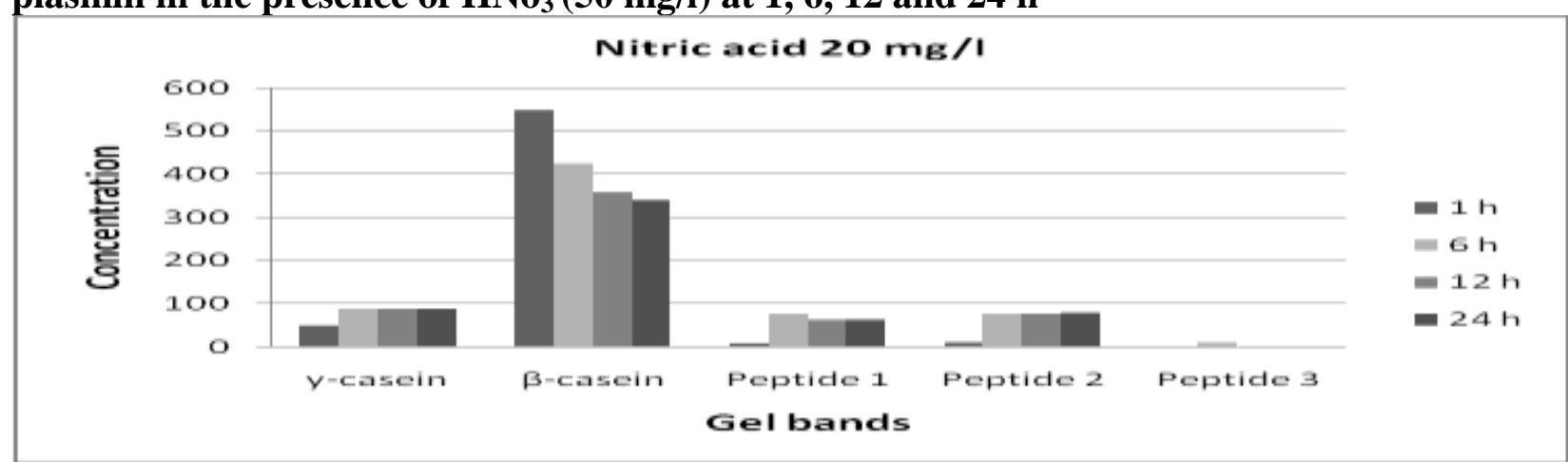

Figure 13. Scanning of Urea-polyacrylamide gel electrophoresis of $\beta$-casein hydrolysed by plasmin in the presence of $\mathrm{HNo}_{3}$ at $(20 \mathrm{mg} / \mathrm{l})$ at $1,6,12$ and $24 \mathrm{~h}$ 


\section{RE FERENCES}

Aimutis, W. R.; Eigel, W. N. (1982), Identification of $\lambda-$ casein as plasmin - derived fragments of bovine $\alpha_{\mathrm{s} 1}-$ casein, J. Dairy Sci. 65: 175 - 181.

Andrews, A.T. (1978a). The composition, structure and origin of proteose-peptone component 5 of bovine milk. European Journal of Biochemistry 90 (1):59-65,

Andrews, A.T. (1978b). Proteolysis in milk and the formation of proteose-peptones. XX International Dairy Congress E,223.

Andrews, A. T. (1983), Proteinases in normal bovine milk and their action on casein, J. of Dairy Res. 50: $45-55$.

Andrews, A. T.; Alichanidis, E. (1983), Proteolysis of caseins and the proteose - peptone fraction of bovine milk, J. Dairy Res. 50: 275 - 290.

Awad, S. (2002) Proteolytic Activity of plasmin on buffalo, cow and goat caseins. Alexandria J. Agri. Res., 47 (3): 4147.

Bastian, E. D. and Brown, R. J. (1996), Plasmin in milk and dairy products: an update, Int. Dairy J. 6: $435-457$.

Cait, N. L. and Patrick, F. F. (1999), The individual or combined action of chymosin and plasmin on sodium caseinate or $\beta$ - casein in solution: effect $\mathrm{NaCl}$ and $\mathrm{pH}$, Lait 79: $423-434$.

Eigel, W. N. (1977), Effect of bovine plasmin on $\alpha_{s 1}-\beta$ and $\kappa$ - A caseins, J. Dairy Sci. 60: 1399 - 1403.
Eigel, W. N. (1981), Identification of proteose - peptone component 5 as a plasmin - derived fragment of bovine $\beta$ - casein, Int. J. Biochem. 13: 1081 - 1086.

Eric, D. B. and Rodney, J. B. (1995), Plasmin in milk and dairy products: an update, Int. Dairy J. 6: 435 - 457.

Farkye, N. Y. and Fox, P. F. (1991), Preliminary study on the contribution of plasmin to proteolysis in cheddar cheese: cheese containing plasmin inhibitor, 6- aninohed - roxanic acid, J. Agric. Food Chem. 39: 786 - 788.

Farkye, N. Y. and Fox, P. F. (1992), Contribution of plasmin to cheddar cheese ripening effect of added plasmin, J. Dairy Res. 59: 209 - 216.

Fox.P.F and Stepaniakl, J. (1993), Enzymes in cheese technology, Int. Dairy J.3, 509- 530.

Lane, C.N. and Fox P.F (1999). The individual or combined action of chymosin and plasmin on sodium caseinate or $\beta$ casein in solution: effect of $\mathrm{NaCl}$ and pH. Lait, 97, 423 434.

Le Bars, D. and Gripon, J. C. (1993), Hydrolysis of $\alpha_{\mathrm{s} 1}-$ casein by bovine plasmin, $73: 337-344$.

Saeman, A.I., Verdi, R.J., Galton, D.M. \& Barbano, D.M.(1988) . Effect of mastitis on proteolytic activity in bovine milk. J. Dairy Sci., 71, $505-512$

Sousa, M.J., Ardo, Y., and McSweeney, P.L.H. (2001). Advances in the study of proteolysis during cheese ripening. International Dairy Journal ,327-345

Swaisgood, H. E. (1982). Chemistry of milk protein. In Developments n Dairy chemistry proteins, ed. P. F. Fox - Applied Science publishers, London, pp. 1 - 59. 


\section{الملخص العربي}

تأثير متبقيات المضادات الحيوية والمنظفات علي النشاط التحللى لانزيم البلازمين على البيتا كازين

ايمان الدخاخني وناهد السيد سليمان

كمــا اشــارت النتـائج ان نشــاط البلازمسين زاد في وجــود

هيدروكسيد الصوديوم وكان ذلك واضحا في فاية فترة التحضين منتجا

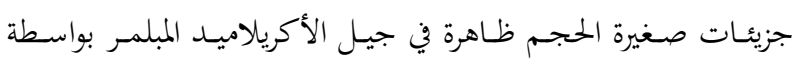

الهجرة الكهربية ولكن وجـود حـامض النيتريك ادى الى تثبيط بطيئ

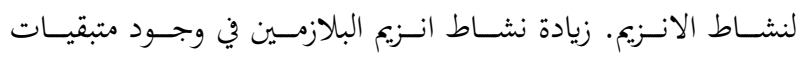

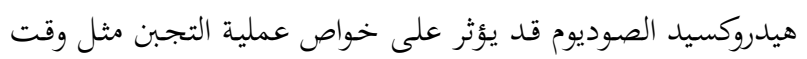

التجبن وقوة وتشريش الخثرة كذلك ظهور مرارة وقصور في طعم الجبن.

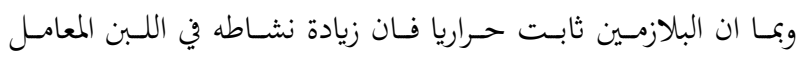

بالتسخين الفوق عالي يسبب تكوين الجيل وقصور ومرارة في الطعم.
يلعب انزيم البلازمين دورا معنويا في تسوية الجبن وخواص المنتجات

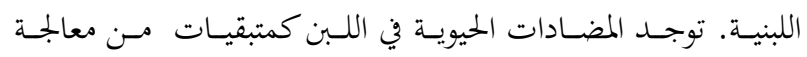

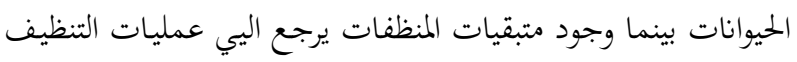

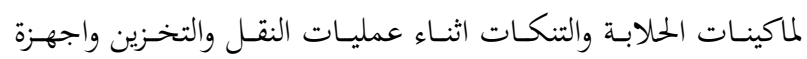



النشاط التحللي للبيتا كازين في نظام المحاليل المقدرة بواسطة الهجرة في

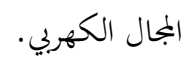

أثبتت النتائج ان البلازمين يحلل البيتا كازين الى ببتيدات صغيرة

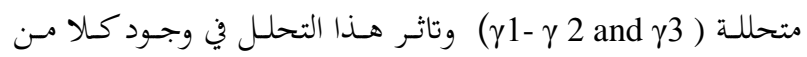

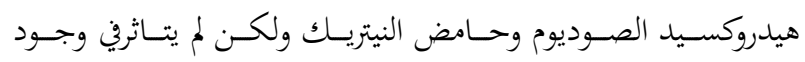

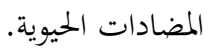

